\title{
UNCONVENTIONAL MONETARY POLICIES AND COMMUNICATION STRATEGIES OF THE EUROPEAN CENTRAL BANK
}

\author{
by Allegra Canepa
}

1. The ECB Intervention in the financial crisis and its communication policies

The financial crisis required the adoption of regulatory interventions and measures to decrease imbalances in the sovereign debt bonds market and to handle the current cash flow crisis.

In this context European Central Bank communication has been crucial.

Indeed, Central Banks communication is instrumental to enhance the transmission of monetary policy as it conveys information on the present and future stance of monetary policy.

This paper deals with the adopted communication policies and their impact on the markets. Two elements stand out: the development of a specific type of measures (unconventional measures) rarely used until that time and the simultaneous adoption of a communication strategy aimed to impact directly and immediatly on the markets. In such a complex situation the decision to adopt poorly tested measures required a careful and somehow innovative approach in communication.

The communicative approach is a key element to be analysed for several reasons, notably: 1) the specific European context characterised by a "multi-country nature of our monetary union" $1 ; 2$ ) the presence of

Associate professor of Economic Law, University of Milan.

1 See P. PRAET, Communicating the complexity of unconventional monetary policy in EMU, ECB Central Bank Communication Conference, Frankfurt am Main, 15 November 2017, available on the website www.ecb.europa.eu. 
a serious financial crisis context requiring a type of communication other than that put in place during economic growth; 3) the growing complexity of adopted measures; and 4) the difficulty in explaining the objectives and potential effectiveness of individual tools within a framework featured by a simultaneous use of several instruments.

Moreover, the decision to devote special care to communication and its possible impact is an increasing need for the ECB for two reasons: the lawfulness of measures and the presentation of interventions by the media of the different member states.

As a matter of fact, as it will be stated in paragraph 3.2, the qualification of a measure as a monetary or economic policy measure on the basis of its defined objectives rather than of the actually achieved impact may be of great relevance for its lawfulness. It is worth underlining such a distinction to acknowledge some discretion of the ECB in its actions.

Moreover, the communication policies adopted by each member state have to be taken into consideration. In fact, a country can emphasize the positive impact of the ECB's measures in some cases while in other cases another country can reveal a completely negative evaluation. On this premise, an evolution of the approach in the ECB's communication policy is able to impact on the policies of the other central banks². There is a serious willingness to develop a decentralized communication system which, in addition to the direct effect of the ECB's communication policy, could be able to produce effects at national level through national central banks.

\subsection{The adoption of unconventional measures}

In response to a strong increase in the spreads of state bonds of some countries (e.g. Greece, Ireland, Italy, Portugal, and Spain ${ }^{3}$ ) joined to serious malfunctions in the monetary policy transmission in the euro

2 About this point M. GAlARDo, C. GUERRIERI, The effect of central bank's verbal guidance: evidence from the $\mathrm{ECB}$, Banca d'Italia, Temi di discussione, $\mathrm{n}^{\circ} 1129$, July 2017.

3 It must be remembered that the yield spread between Italy's and Germany's 10year government bonds in the first half of 2011 has remained under 200 basis points while in November it strongly widened to 500 basis points. Only at the end of 2012 it dropped to approximately 300 basis points. About this point in particular M. FALAGIARDA, S. REITZ, Announcement of ECB unconventional programs: implication for the sovereign risk of Italy, Kiel Working paper n.1866, August 2013. 
area (characterised by a great difference among country) and increasingly lower short-term interest rates, the ECB adopted non-standard monetary policy responses ${ }^{4}$.

Such critical issues required targeted interventions able: 1) to counteract the weakening of the monetary policy transmission mechanism 5 ; 2) to maintain stability; and 3) to stimulate bank lending to the real economy. Hence specific programmes have been adopted by ECB: Enhanced Credit Support 6 ; Securities Market Programme (SMP $)$ i.e. direct purchase of bonds on the secondary market without any preset indication of the purchase amount; Outright Monetary Transaction (OMT) commitment to purchase government debt; Long-Term Refinancing Operations (LTRO $\left.{ }^{8}\right)$ without any ex ante 9 quantitative limits and loans for banks buying government debt (TLTRO) which was then planned with pre-set interest rates joined to an extension of the so called "eligible collateral list" 10 and of the intervention duration (from 6 to 12 months) ${ }^{11}$.

4 It is a qualification deriving from the economic doctrine and that is not confirmed either by the Statute of the ECB which does not clarify, by submitting a list of them, which are unconventional measures. About this point in particular F. BASSAN, Il parametro di legittimità delle misure non convenzionali della $B C E$, in "Banca, Impresa Società", n. 2, 2015, pp.173 -198.

5 About this point in particular V. CONSTANCIO, A new phase of the ECB's monetary policy, ECB workshop on non-standard monetary policy measures, 6 October 2014, available on the website www.bce.it.

6 In particular with the Covered Bond Purchase Programme (CBPP1) followed in November 2011 by the CBPP 2 .

7 Introduced by ECB on 10 May 2010 and extended on 7 August 2011 to Italy and Spain. The latter in 2013 were the two countries for which it was mostly used.

8 In particular the LTRO programme was widely used to encourage a drop in interest rates, a reduction of the systemic risk and to mitigate the effects of the credit crisis.

For a detailed analysis of these 3 programmes see A. KRISHNAMURTHY, S. NAGEL, A. VISSING-JORGENSEN, ECB policies involving government bond purchases: impact and channels, December 2015, available on the website faculty.haas.berkeley.edu.

9 The programme was introduced on 6 September 2012.

10 About this topic see the Decisions of the ECB of May 2010 "on temporary measures relating to the eligibility of marketable debt instruments issued or guaranteed by the Greek government (2010”), of 31 March 2011 "on temporary measures relating to the eligibility of marketable debt instruments issued or guaranteed by the Irish Government (2011)", of 7 July 2011 "on temporary measures relating to marketable instruments issued or guaranteed by the Portuguese Government (2011)'. About this point see in particular C. TUCKWELL, A. MENDONÇA, The global crisis and unconventional monetary policy: ECB versus FED, Working paper CEsA GCS 141/2016, available on the website of Lisbon University.

${ }^{11}$ Followed by the most recent one Quantitative easing (QE), as described later on. 
These operations, although showing different characteristics, shared two elements, the legal basis and their underlaying tasks which is supplementary to the action on the interest rates ${ }^{12}$.

With to regard to the first element, the Treaty provisions involved are the following: Article 127 TFUE identifies a general supporting competence to European policies ${ }^{13}$ and Articles 18 and 20 Protocol $\left(\mathrm{N}^{\circ} 4\right)$ on the Statute of the European System of Central Banks and of the ECB provides for general principles governing credit and open market operations and enabling the ECB to implement policies of monetary control it deems appropriate ${ }^{14}$. Moreover, Article 18 is stating that in order to achieve the objectives of the ESCB and to carry out its tasks, the ECB "may operate in the financial markets by buying and selling outright (...) or under repurchase agreement, by lending and borrowing claims and marketable instruments, and conduct credit operations with credit institutions and other market participants, with lending being based on adequate collateral".

The adoption of such unconventional measures, in addition to ensuring a wider range of interventions to reduce the default risk of countries facing difficulties thanks to the strengthening of "price stability in the euro area" 15 , made it difficult to understand the ECB's monetary policies and to predict the outcome. This situation increased the need for communication. The ECB has strengthened its efforts to explain measures not commonly used and scarcely known by the public. Furthermore, some member States were somehow dubious about some of these measures, as will be described on paragraph 3.1, not only about

12 About this point in particular P. Cour-Thimann, B. WinkLer, The ECB's nonstandard monetary policy measures. The role of institutional factors and financial structures, ECB working papers, $\mathrm{n}^{\circ} 1528$, April 2013, available on the website ww.ecb.europa.eu.

${ }^{13}$ Article 127 (1) states that "the ESCB shall support the general economic policies in the Union with a view to contributing to the achievement of the objectives of the Union as laid down in Article 3 of the Treaty on European Union". It allows to resort to a wide range of interventions ti pursue indicated objectives.

14 Pursuant to art.20 of the Statute this possibility requires a decision by a majority of two thirds of the votes cast.

${ }^{15}$ See the press release of 7 August 2011 stating, with reference to the SMP, "This programme has been designed to help restoring a better transmission of our monetary policy decisions - taking account of dysfunctional market segments - and therefore to ensure price stability in the euro area". 
their effectiveness but also mainly about their legitimacy with regard to the ECB's institutional tasks ${ }^{16}$.

\section{Communication as an instrument of monetary policy}

Over the last years communication has been gradually developed not only by the ECB but also by all central banks ${ }^{17}$ in order to improve transparency and accountability. However, in such a period of financial market stress, the ECB's communication has gained a stronger role ${ }^{18}$ and it has revealed essential in reducing volatility and preparing markets to accept its decisions.

In particular, the ECB has decided to review its communication strategy (dissemination of information on its actions about interest rates and on various measures adopted or to be adopted) ${ }^{19}$ and take into consideration the instruments and dissemination methods through media

16 This mainly refers to OMTs which have been the subject of a judgement by the Court of Justice following a preliminary reference of the German Federal constitutional court about their lawfulness with regard to the ECB's mandate. About this point see section 3 of this chapter.

On the more general issue of implications and possible changes in the role of the ECB refer in particular to F. CApriglione, G. Semeraro, Il Securities Market Programme e la crisi dei debiti sovrani. Evoluzione del ruolo della BCE, in "Rivista Trimestrale di Diritto dell'Economia.", n. 3, 2011, pp. 257-283.

${ }^{17}$ It must be remembered for instance that only in 1994 the Federal Reserve decided to disclose immediately its decisions on interest rates while before that time markets had to infer basically whether the FED committee in charge of monitoring open market operations, the FOMC (Federal Open Market Committee) had decided to change its rate on federal funds.

On the general issue S. Dale, A. Orphanides, P. Osterholm, Imperfect Central Bank Communication: information vs distraction, in "International Journal of Central Banking", June 2011, pp. 3-39.

18 On the evolution leading over the years to abandon "confidentiality" in favour of transparency refer in particular to B. WINKLER, Which kind of transparency? On the need for clarity in monetary policy making, ECB Working Paper $n^{\circ} 26 / 2000$, available on the ECB's website; O. Issing, Communication, Transparency, Accountability: Monetary Policy in the Twenty-First Century, in "Federal Reserve Bank of St. Louis Review" 87, March/April 2005 p. 65-83 and available on the website http://research.stluoisfed.org; D. Masciandaro, D. Romelli, From silence to voice: monetary policy, Central Bank governance and communication, Baffi Carefin Centre research paper series, May 2016, $\mathrm{n}^{\circ} 2016-27$.

${ }^{19}$ It must be noted that, already before the crisis, the ECB's degree of transparency 
anticipating, whenever possible, announcement effects (in particular through the declarations of the President) ${ }^{20}$.

The intention of the ECB has been to publicly define the scope and implementation of these unconventional policies, as well as to build a common understanding of their effectiveness.

In this way the ECB seeks to capitalize on the growing role the media have played in the recent years with regard to depositors and stock markets ${ }^{21}$ view of pursuing market stabilization and counteract the effects of the crisis.

The dissemination of official news carefully prepared - mainly carried out through declarations of the president and press releases after meetings - becomes a sort of "additional" instrument of monetary policy that reduces uncertainty 22 and brings about a positive reaction on the markets ${ }^{23}$. Such an effect implicitly strengthens such measures. The strong intertwinement between "communication intensity" and effects on the markets can be noticed considering the dissemination of press releases and declarations of the press conferences triggering an immediate increase of operations on the market 24 . In some cases, such a situation can result even before the ECB's programmes are put in place or even if they no more are (as in the case of OMT).

and attention to communication were much higher than those of other central banks of the member states. On this point in particular M. Ehrmann, M. Fratzscher, The timing of Central Bank communication, ECB working paper series, $\mathrm{n}^{\circ} 565$, December 2005, available on the website www.ecb.europa.eu.

20 The President of the ECB pointed out this element in his speech at the conference De Nederlandsche Bank 200 years: Central banking in the next two decades, held in Amsterdam, 24 April 2014 and available on the website of the ЕСВ.

${ }^{21}$ About this point in particular N.J. Ferguson, D. PhiLIP, H.Y.T. LAM, J.M. GuO, Media content and stock returns: the predictive power of press, 2014, available on the website dro.dur.ac.uk.

22 Uncertainty can take different forms. It can be unresolvable (aleatory uncertainty), epistemic (represent a known and resolvable lack of knowledge) and ontological (represent a state of complete ignorance). About this point in particular A. GIESECK, Y. LARGENT, The impact of Macroeconomic Uncertainty on activity in the Euro Area, in "Review of Economics", 2016, p. 25.

${ }^{23}$ A first example of communication as an instrument to affect markets is that of 1990 in New Zealand by the Reserve bank of New Zealand. On this point refer in particular to G. Graeme, J. Wright, Open mouth operation, in "Journal of Monetary Economics", n. 2, 2000, pp. 489-516.

${ }^{24}$ This ability of communication to "move" markets, even if in a minor way, had already been pointed out in 1994 with the Federal Reserve. About this point refer in partic- 


\subsection{Communication design in crisis time}

During the financial crisis the channels of communication have been adjusted with regard to the dissemination tools such as structure (press release, interview, etc.); disclosure (announcement aimed at providing data or explaining strategy (details and measures); methods of drafting/disseminating (language and clear use of the terminology); timing (periodic communications, communications made at certain time when markets are either open or closed) and the purposes to be implemented. In fact. As a matter of fact, if these elements are not carefully weighed up, a wrong or incomplete perception of what was introduced with consequent impact on the markets can arise.

The relevance of these aspects and their management is also underlined by the existence of a special office in the ECB's structure composed of different branches according to the recipients and the tools of communication ${ }^{25}$.

All these elements have to be underlined especially since they allow us to better understand the action of ECB and advantages and disadvantages of these communication measures.

As far as the content of the measures is concerned, it usually includes the objectives of the adopted monetary policies, the modes used to achieve them, the possible impact on the evolution of the economic conditions and on inflation.

As for the instruments used to disseminate information, strategic decisions are related to the choice of the used tools (television, Internet, etc.) and the procedure (an interview, a press release, or a more detailed technical document on the decisions taken by the board of governors). The OMT programme highlights the high relevance of a communication strategy, the importance of timing and its possible "ultra-effectiveness".

ular to S. Demiralp, O. Jorda, The response of term rates to Fed Announcement, in "Journal of Money, Credit and Banking", n. 3, 2004, p. 387-405; M. Ehrmann, M. FRATZSCHER, Trasparency, disclosure and the Federal Reserve, ECB working paper series, $\mathrm{n}^{\circ} 457,2005$, available on the website www.ecb.europa.eu. On the effects of communication during the crisis refer in particular to the discussion paper, Working paper Seiries BCE $n^{\circ}$ 2020, June 2017, available on the website www.ecb.europa.eu.

25 The branches are: 1) External PR 2) Relations with global media 3) Language services 4) Web and digital communication. They are available clicking the website www.ecb.europa.eu. 
Focusing then on the overall communication aspect, the ECB adopts a "classic" scheme that takes into consideration the decision of the Board of Governors on general principles as well as the specific conditions of various operations. Such a decision is made known through a press release and a conference of the President (including question time where he illustrates the measures, the technical details (the latter are generally the subject of the press release) and the expected effects. Information is then immediately published on the ECB's website in order to be easily accessible.

To orient the market towards a more optimistic or pessimistic attitude on short-term and long-term perspectives ${ }^{26}$ it is important not only to define what information is to be released (including the choice of keywords) but also the communicative capacity (capacity to transmit optimism, safety and effectiveness of the measures presented at stake) of the person in charge ${ }^{27}$. All in all, as said by Trichet this is "the art of external communication"28. Moreover, a press conference announcing that some measures have been taken is usually able to generate a great surprise effect on the markets and can also be followed by more serious consequences.

Within this framework the timing appears also relevant from different points of view, i.e. for a contingent reason and a more general one. The former concerns the aforementioned capacity to produce effects on the markets in the short term and the consequent importance of choosing the moment for communication (in particular in the case of closed or open markets).

The most general aspect concerns the ability to illustrate and make the adopted measures understandable, and to communicate when implementation or modification could be put in place. This lat-

${ }^{26}$ On this point in particular D. AmaYA, J-Y. FILBIEn, The similarity of ECB's Communication, 2015, available on the Website econpaper.repec.org.

27 In this regard the comparison made on two presidents of the Federal Reserve and on their ability to communicate and influence the markets carried out by K. THORARINSSON, A. ESHRAGI, The financial Impact of FED Policy Statements and Chairman sentiment: the case of gold and silver market, 2013 is very interesting, available on the Website www.ssrn.com.

28 J.C. TRICHET, keynote speech at the new year's reception of the international Club of Frankfurt Economic Journalist, 25 January 2005, Frankfurt am Main, available on the Website www.ecb.europa.eu. 
ter effect is a direct consequence from the choice to prepare and publish press releases at a predefined monthly frequency - relevant especially during the crisis - so that the dissemination of the news can be as regular, organised, punctual, clear and non-contradictory as possible.

As a consequence of this choice, not using simple meeting reports, but mainly of the president's press releases and press conferences (along with other tools, such as for example the monthly bulletins ${ }^{29}$ ) guarantee a detailed and precise illustration of the decisions, of the stability risks and of the growth perspectives.

This process is costly in terms of time and resources. But maximising the effectiveness of communication is crucial.

\section{The effect of OMT programme communication on the markets}

The structure of the unconventional operations is organised in two phases: 1) the press release (published on the ECB website announcing the decisions taken at the Board meetings) 2) the press conference illustrating technical aspects and aims of the measures. At a first glance these elements may seem of little relevance compared to the content and implementation of the measures themselves. Actually, the case of definitive monetary operations shows the importance of a communication that goes beyond the effective implementation of the measures. As a matter of fact, what is relevant for the production of effects on the markets is the press release and the press conference on the

${ }^{29}$ In the monthly bulletin of November 2002, the ECB pointed out as "The monthly press conferences held by the President and the Vice-President and the Monthly Bullettin are two of the most important communication channels adopted by the ECB (....) The monthly press conference includes a question and answer session (...) and provides a platform for the explanation of monetary policy decisions to the public. Transcript are made available on the ECB's website only a few hours later", p. 64, available on the Website www.ecb.europa.eu.

Also other communications must be added to the aforementioned types. Such communications regard, for instance, the opinions of the Executive Board, the statistical reports and projections of the ECB and published in March and September), the texts of the speeches of conferences, the results of the bank lending survey, to the decisions made together with the European Commission and the International Monetary Fund. 
conditions making such interventions necessary and the timing for an improvement of the economic framework ${ }^{30}$.

Regardless of its structure, the modes with which the OMT programme was adopted, the implications with regard to its functions and the role played by the ECB, it is especially interesting from the communicative point of view.

Because of the intricacy of the situation and the peculiarity of the instrument it was necessary to carefully analyse the presentation to the markets with respect to times and procedures. In July $2012^{31}$ President Draghi presented the OMT program at a conference in London. The OMT key elements were already approved before by the board of governors and then recapped together with its technical features at a press conference following the board. There were then further meetings that defined and partly modified the related decision and direction plans. On 6 September 2012 the Executive Board explained the technical features of the programme including the absence of an ex ante quantitative limit of purchase and the concentration of purchases on bonds with a residual life not exceeding three years ${ }^{32}$.

The purpose of these measures was described as "safeguarding an appropriate monetary policy transmission and the singleness of the monetary policy" ${ }^{33}$. Therefore, although these measures were actions addressed to supporting the purchase of government bonds of the countries in trouble, they were described as an instrument mainly affecting transmission of money and inflation.

The most interesting element, however, is that such a communication strategy produced effects on the markets. As a matter of fact, there was a positive effect immediately after the press conference on the basis of the only elements provided by the President and regardless of the time of entry into force of the measures.

${ }^{30}$ About this point in particular see the press conference by Mario DRAGHI of 6 September 2012, available on the ECB Website.

31 The speech was held at the Global Investment Conference in London on 26 July 2012.

32 At its meeting on 5 and 6 September the Executive Board of the ECB had adopted the draft decision on OMTs which repealed the Decision ECB/2010/5 as well as a draft address that had subsequently been amended at the meetings of 4 October and 7 and 8 November 2012.

${ }^{33}$ See есв Press release, Technical features of Outright Monetary Transaction, 6 September 2012, www.ecb.europa.eu. 
This means that we are dealing with not only an example of socalled "announcement effect" but something more, given that immediate effects have been produced, whose benefits have gone on in the case of a programme never used, i.e. only as a consequence of its adoption and its potential use.

Unlike what happens traditionally when a decision produces binding legal effects immediately after it has been taken, over the crisis we observed a different phenomenon, i.e. an act can produce effects on the markets immediately after the communication. As a matter of fact, both the so-called bank bailouts and the OMTs themselves represent clear exceptions to the traditional theory.

In the first case there were effects on the markets following the sole announcement that banks would have been guaranteed through state interventions. This point was highlighted by the Commission itself which, in its decision on the WestLB case, underlined that "The fact that no approval of the government and the Parliament had been given and no provisions were made in the government's budget (...) seems not crucial because the government had communicated its principal engagement in a political declaration vis-à-vis the public and the markets, which is treated by the market as a binding commitment" 34 . Hence even before the legal implementation of the measure, market effects occurred as if it had been adopted. However, as in this case, the effects were immediately produced, and the real implementation followed them.

On the other hand, the OMT's case is quite different. The programme has been already effective on the markets when its adoption was announced regardless of any effective implementation.

This situation is quite clear in the cases of the Italian and Spanish government bonds. In such cases the announcement of the OMTs immediately gave rise to positive effects, blocking the increase in risk that characterised these bonds up to then ${ }^{35}$.

${ }^{34}$ Commission Decision C(2008)1628, State Aid, case NN 25/2008 WestLB riskshield, Germany, 30 april 2008, www.europa.eu/competition/state_aid/cases, p. 38.

${ }^{35}$ Namely on the effects in the Italian case see M. CASiraghi, E. GaIotTi, L. RoDANO, A. SECCHI, The impact of unconventional monetary policy on the italian economy during the sovereign debt crisis, in BANCA D'ITALIA, "Questioni di economia e finanza", n.203, 2013, available on the Website www.bancaditalia.it. 


\subsection{The announcement effect on spanish and italian bonds: benefits and problems in its application}

The two cases appear to be particularly significant for several reasons, which can be summarised as follows: 1) a strong and immediate impact on markets just after the approval of the OMT; 2) a benefit produced regardless of the effective adoption of the measures; 3 ) the lack of the conditions for its implementation.

With regard to the Spanish case, the announcement effect of measures such as the European Stability Mechanism (ESM) and the OMT, both aimed at supporting a state in difficulty can be compared since they produced opposite outcomes. In the Spanish case, firstly, the announcement to use the ESM was followed by a negative effect i. e. a further increase in the risk for bonds on the market. Secondly the announcement of a possible recourse to the OMT resulted in a positive reaction so that the risk on the markets decreased immediately ${ }^{36}$.

In the past, actions counted substantially more than words, given that central banks decided to speak only in exeptional circumstances ${ }^{37}$. On the contrary in this case words counted more than actions.

This is why some economists have defined the OMT as "one of the most and successful monetary policy communications in decades" 38 .

The reasons for the apparent greater effectiveness of the OMTs or, better of their announcement, are probably closely linked to some features mentioned in this programme such as the availability of unlimited funds for operations and the ECB's waiver of being a privileged creditor (elements not found in the ESM).

A more thorough examination shows that there are two requirements for admissibility of the OMT, namely the presence of a program under the ESM Fund and a constant bond issue which, in some of the countries involved, particularly in Italy and Spain, made them even inapplicable.

\footnotetext{
${ }^{36}$ About this point in particular refer to, A. BELKE, Non-standard monetary policy measures - magic wand or tiger by tail?, Ruhr Economic Papers, October 2013.

${ }^{37}$ See Communication of monetary policy decisions by central banks: what is revealed and why, BIS papers $\mathrm{n}^{\circ} 47$, may 2009, available on website www.bis.org.

38 M.M. Fratzscher, F. Giavazzi, R. Portes, B. Werder Di Mauro, C. Wyplosz, A call for support of the European Central Bank's OMT Programme, 19 July 2013, available on the Website https://berlinoeconomicus.diw.de.
} 
As a matter of fact, in Italy, on the one hand, the announcement produced positive results on the market of state bonds immediately . However, it was not possible to apply the OMTs immediately given that Italy had not requested support under the ESM. In Spain, on the other hand despite the presence of an intervention under the ESM, the action of the OMTs did not affect the primary market but only the secondary market and in any case for a short period as the conclusion of the intervention by ESM was scheduled for December 2013.

In addition to considerations on the effectiveness of communication policy, an open question is what the elements producing immediate positive market effects regardless of an effective implementation are.

According to Cœurè, a member of the Executive Board of the ECB, the reasons why the OMTs were able to produce differentiated positive effects in different Member States ${ }^{39}$ lie precisely in their structure and in their ability to be identified as a sort of insurance for the bonds involved. Moreover, as for other operations, the ECB had waived its status of privileged creditor. These elements would have led to an increase in the level of market confidence ${ }^{40}$.

As pointed out, the OMTS as interesting "communication potentials" have also generated doubts related to their potential use and specifically related to: 1) the possible effects arisen from the purchase of bonds characterised by a high level of risk 2) a differentiation of effects produced in different countries (specifically, far greater effects in the countries in greater difficulty such as Spain and Italy and almost none in others like France ${ }^{41}$ ) 3) the possibility of fully re-establishing the powers provided for the ЕСВ. Analysing these aspects is

${ }^{39}$ Namely, a decrease in the default risk for Italy and Spain and a redefinition for Portugal has emerged. Notably, A. Krishnamurthy, S. NAgel, and A. Vissing-JorGENSEN, ECB policies involving government bond purchases: Impact and channels, ECB Working paper 2014, available on the Website www.ecb.europa.eu.

40 Courè, speech at the conference organised by the Centre for Economic Policy Research, The ECB and its OMT programme, 2 September 2013, available on the Website www.ecb.europa.eu.

${ }^{41}$ On this point in particular, C. Altavilla, D. Giannone, M. Lenza, The financial and macroeconomic effect of OMT Announcement, ЕСB Working Paper Series n ${ }^{\circ} 1707, \mathrm{Au}-$ gust 2014, available on the Website www.ecb.europa.eu and P. BURRIEL, A. GALESI, Uncovering the heterogeneous effects of ECB unconventional monetary policies across euro area countries, Banco de Espana, documentos de trabajo no. 1631, 2016, available on the Website www.bde.es. 
especially useful to give a more precise picture of the risks/benefits of ECB measures.

\subsection{Lawfulness issues of the program and its effectiveness}

The OMT program, while not having been enforced, was nevertheless object of judicial review ${ }^{42}$ regarding its compatibility with the Treaty provisions on monetary policy and on the prohibition on financial assistance to Member States ${ }^{43}$.

The German Federal Constitutional Court requested a ruling from the Court of Justice of the European Union on whether: 1) the OMT programme is a monetary policy measure and then falls within the scope of the ECB's mandate; 2 ) the measure meets the prohibition on monetary financing laid down in Article 123(1) TFEU.

The German Court pointed out that the "mandate of the ECB to" cannot go beyond monetary policy, while in general Member States are entitled to run economic policies. According to the CJEU's assessment, the OMT Decision impacts on Member States' competences in economic policy in some ways.

It was underlined that the $\mathrm{ECB}$ is bound to a clear mandate being closely linked to the struggle against inflation, where it is hard to find legal grounds for the adoption of programs such as the OMT. On the contrary ECB defended the lawfulness of the program by deeming it to be eligible as an intervention aimed at unlocking the transmission channels of the European Union ${ }^{44}$.

42 A reference for a preliminary ruling from the German Bundesverfassungsgericht, led to the Judgment of the CJEU of 16 June 2015 in P. Gauweiler and Others $v$ Deutscher Bundestag, Case C-62/14, ECLI:EU:C:2015:400 where doubts were raised, included by sone Member States in their observations, about the admissibility of the reference itself.

${ }^{43}$ With this respect the Court pointed out that the fact that the purchase of Government bonds takes place on the secondary market and not on the primary one is not relevant for the purposes of the compatibility with article 123 TFEU. About this point in particular see F. CAPRIGLIONE, Mercato regole democrazia. L'UEM tra euroscetticismo e identità nazionali, Torino, Giappichelli, 2013, p. 123 sgg..

44 In particular, according to ECB the transmission channels of the monetary policy do not work like mechanisms that trigger immediate effects, but they rather work as a framework used by ECB to launch a series of "drives" targeting real economy. Moreover, they may be affected by exogenous factors such as a crisis, which might critically alter 
In particular the German Federal Constitutional Court focused on whether the ECB would have been empowered to introduce OMTs in the perspective of reducing the interest spreads. However the CJEU's point of view in Gauweiler was considerably different. It affirmed that, when specific objectives occur, such a measure fall within the monetary policy 45 .

So, the Court focused exactly on the aim that was pursued and it recognized the lawfulness of a program for the purchase of Government bonds on the secondary markets like the OMT ${ }^{46}$.

As a matter of fact, the extraordinary situation originated by the crisis prevented the pursuing of the monetary policy and then required an intervention aimed exactly at unlocking it and restoring the ordinary channels. According to the ECB, monetary policy may be affected by elements external to the transmission channels. Such elements can disrupt the proper functioning of the signals delivered by the ECB: an international political or economic crisis, among other factors, may severely interfere with the 'impulses' that the ECB delivers via the monetary policy transmission channels ${ }^{47}$.

Such an action of restoring the ordinary channels should be brought about exactly by the OMT program. In this respect any further conse-

the drives launched by ECB. In these cases, ECB deems to be competent to unlock them. Such arguments are also discussed in his Opinion by Advocate General CRUZ VILLALÒN in GAUWEILER, ECLI:EU:C:2015:7, points 115 and ff.

45 The Court has held that in order to determine whether a measure falls within the area of monetary policy it is appropriate to refer to the objectives of that measure principally. In "addition the instruments which the measure provide in order to achieve those objectives are relevant (see the judgment of 27 November 2012 in Pringle, C-370/12, EU:C:2012:756, paragraphs 53 and 55).

46 See among others F. BASSAN, Le operazioni non convenzionali della BCE al vaglio della Corte costituzionale tedesca, in "Rivista di diritto internazionale", n. 2, 2014, p. 361-393; A. De Petris, Un rinvio pregiudiziale sotto condizione? l'ordinanza del Tribunale costituzionale federale sulle "Outright Monetary Transaction" and A. DE MARTINO, Le "Outright Monetary Transaction" tra Francoforte, Karlsruhe e Lussemburgo. Il primo rinvio pregiudiziale del "Bverfg", both available on the website www.federalismi.it, 4, 2014; D. Rossano, Legittimo il programma "OMT": la Corte di Giustizia dà ragione alla BCE, in "Rivista Trimestrale di Diritto dell' Economia", n. 2, 2015, pp. 52-93 and A. TroIsI, Gli strumenti di intervento della BCE e le prospettive dell'Unione Europea, in "Rivista Trimestrale di Diritto dell' Economia", n. 2, 2015, pp. 94-107.

${ }^{47}$ See conclusions by Advocate General Cruz Villalón in Gauweiler, cited above in note 44, p. 115. 
quences possibly entailed by the program, and not attributable to the monetary policy, such as a stabilization of the Euro area, take then second place. Moreover also the remarks on the proportionality of the intervention with regard to the objectives - this aspect being characterized by complex technical choices- cannot be based upon what was pointed out by ECB on the occasion of the adoption of the measures and about the relevant exercise of its discretionary power.

In addition, the programme introduced specific features such as selectivity and conditionality as government bonds must not be purchased on secondary markets by the ESCB. Such conditions have to avoid that the ESCB's action "has an effect equivalent to that of a direct purchase of government bonds from the public authorities and bodies of the member States" 48 .

The conclusion of the Court leads to rethink the effects of the implementation of the measures. On the one hand, as already pointed out, there were remarkable effects on the markets, such as reducing Government bonds pressure in some of the most distressed countries, notwithstanding any effective implementation. The OMT program managed then to achieve positive results with respect to the sovereign debt crisis even without using any resources 49 .

However, on the other hand, as highlighted by Mr. Draghi in a conference in 2014, we missed the opportunity to achieve positive results concerning growth, even if indirectly, through a greater liquidity transmission by the banks ${ }^{50}$. The President stated that not all objectives have been achieved as "these positive developments in the financial sphere have not transferred fully into the economic sphere. The economic situation in the euro area remains difficult"

To overcome the weaknesses of the OMT programme, the ЕСB then

${ }^{48}$ See Gauweiler cited above, n. 42, p. 9.

49 About this matter see F. CAPriglione, G. Semeraro, Crisi finanziaria e dei debiti sovrani. L'Unione europea tra rischi ed opportunità, Torino, Giappichelli, 2012, p. 137 sgg..

50 About this point in particular see V.V. ACHARYA, T. EISERT, C. EufingER, C. HIRSCH, Whatever it takes: the real effects of unconventional monetary policy, Safe Working Paper $n^{\circ} 152 / 2016$, available on the website www.ssrn.com.

${ }^{51}$ M. Draghi, Monetary policy in the Euro area, Opening keynote speech, 21 November 2014, Frankfurt European Banking Congress, available on the website www.ecb.europa.eu. 
intervened in January $2015^{52}$ by adopting a different program called Quantitative Easing (QE). Such a program, differently from the OMT, was aimed at increasing the liquidity of the system, which would then grant more liquidity to banks and consequently to companies and private clients. Moreover, since the QE was not subjected to the same conditions required by the OMT it could be implemented more extensively. Such an intervention was aimed at going beyond one of the main obstacles towards the economic recovery which poor liquidity at disposal of banks and the capitalization difficulties affecting the system hindered to achieve.

The ЕCB has made significant changes with respect to the original design of the programme started in January 2015 (particularly on the duration and the size). Indeed the ECB communicated that purchases will carry on "until the end of March 2017, or beyond, if necessary, and in any case until the Governing Council sees a sustained adjustment in the path of inflation consistent with its aim of achieving inflation rates below, but close to, 2 per cent over the medium term" 53 .

The extension of the QE programme raised some questions on its potential adverse consequences ${ }^{54}$ and on its legality. In particular the German Constitutional Court questioned the legality of ECB's bond buying programme ${ }^{55}$.

\section{Benefits and risks of ECB 's communication strategy}

An evaluation of the ECB's communication policy made clear that the main advantages concern the effects produced on the markets as

52 The QE was adopted by the Council on 22 January 2015, but the actual operations started on 9 March 2015. See M. DrAGHI, Introductory statement to the Press Conference, Frankfurt 22 January 2015 and $i d$., Nicosia 5 March 2015, available on the website www.ecb.europa.eu.

${ }^{53}$ M. DRAGHI, Introductory statement to the press conference, 20 October 2016, available at: https://www.ecb.europa.eu/press/ pressconf/2016/html/is160908.en.html.

54 About this point in particular see G. ClaEYs, A. LEANDro, A. MANDra, European central bank quantitative easing: the detailed manual, February 2015 and G. CLAEYs, A. LEANDRO, The European Central Bank's quantitative easing programme: limits and risks, February 2016, available on the website www.bruegel.org.

55 Request for a preliminary ruling from the Bundesverfassungsgericht (Germany) 
well as the increase in transparency and accountability of activities and decisions. However in order to make a comprehensive analysis of the communication role it is necessary not to limit the investigation to individual cases but to make an overall assessment including the disadvantages, or better the risks, and considering that not only the immediate effects but also the medium term ones should be taken into account.

Consequently, it is worth considering the difficulty of identifying the ideal level of communication with regard to the relevant effects on the markets ${ }^{56}$. In this perspective the choice of how many details may be communicated is not easy when it includes elements concerning the efficacy of the measures which depends on markets appreciation and reaction. Therefore, the result depends on the different kinds of recipients on the market (either specialized operators or unexperienced consumers) and on their different ability to understand and rationally evaluate the measures.

In his context what emerges is the high complexity of developing a uniform and at the same time multi-country communication, so that it might be straightforward, identical, and context-sensitive in all EU member states.

At the end, the strong increase in communication can also determine some negative effects in the medium and long run when the announced measures are not eventually applied and do not bring about the expected results. As a matter of fact, in this case, without adequate information on the reasons for the failure to achieve the expected goals and on possible new corrective measures, an effect opposite to the one expected could arise and drive to a decreased confidence in the ECB's ${ }^{57}$ capacity to intervene and define adequate measures.

lodged on 15 August 2017 - Heinrich Weiss and Others, case C-493/17, OJEU 2017/C402/11.

56 About this point in particular see C. RosA, G. Verga, Is ECB's communication effective?, April 2005, available on the website www.ssrn.com and J. DE HAAN, ECB Communication: effects on expectations, in this volume.

57 With this respect concerning not only ECB but also all of the central banks in particular see I. VAYID, Central bank's communication before, during and after the crisis: from open-market operations to open mouth policy, Bank of Canada, Working paper, 2013-41, available on the website www.bankofcanada.ca. 


\section{Conclusions}

This analysis suggests that unconventional measures look quite interesting per se both for the novelty they represent and most of all for the communicative innovations. They lead to consider the importance of the communication policies as an additional tool in the framework of the measures adopted during the financial crisis.

The intensity and duration of the crisis made it necessary for the ECB to carry out a double action so as to support Member States and to supply liquidity in order to boost both the banking system and the economic recovery. This implied as an indirect consequence the need to enter an uncharted territory as pointed out in a European Parliament report of September 2015. This report highlights the evolution undergone by the ECB's monetary policy in the aftermath of the financial crisis and how such an element can inevitably have a future impact. The report underlines how "monetary policy has entered uncharted territory following the great financial crisis. While prior to the crisis it had broadly converged toward one with a price stability (inflation) target and a short term interest rate as a policy tool, there is now a $2^{\text {nd }}$ variant of monetary policy, which involves varying both the size, and perhaps, the composition of a central bank's balance sheet, with implications for monetary policy and also for financial stability" 58 .

At the same time ECB, in order to tackle the markets' strong crisis of confidence, needed to adopt unconventional measures and to support them through a careful communication, which became an unavoidable element for their efficacy as witnessed in the case of the OMT. It is clear that it can trigger positive effects on the markets since it can determine an anticipated reaction to the measures (of both operators and savers) rather than a reaction after having enforced them. Hence the OMT case is emblematic since positive effects took place immediately after the announcement was given and even if it was not followed by an effective enforcement of the measure. The fact that such measures have significantly impacted on the financial markets for a more than two years period after the announcement, proved that the ECB envisaged produc-

58 European Parliament, Directorate-General for Internal Policies, Interaction between monetary policy and bank regulation, IP/A/ECON/2015-07, September 2015, available on the website www.europarl.europa.eu. 
ing those effects and the OMT press release was not only a preliminary act. Therefore the announcement seems an example of regulation by information ${ }^{59}$ that resulted in reducing the spreads and making its application unnecessary.

Furthermore, it is worth underlining a certain communicative ability of the ECB as compared to other central banks even outside Europe, which can evolve in an increased appeal of the programs for the investors ${ }^{60}$.

Indeed the communication element was used by ЕCB with a double intention, in order to try and "justify" the consistence of the programs adopted on the base of its competencies and in order to be able to exercise a certain discretionary power, while envisaging increasingly sophisticated monetary policy tools. This was done in cases such as that of the OMT but also for the QE program that have been subsequently adopted. Both actions were introduced as a measure on inflation and not as a measure aimed at supporting the Government bonds market.

Yet, as already pointed out, this did not prevent the lawfulness of similar measures from being brought to the Court of Justice, in light of TFEU provisions, and especially against the virtual implementation of a wider ECB's mandate. The Court made it clear that certain conditions needed to be respected. However, after having defined the concept of monetary policy, the Court accepted in substance the introduction of such measures by authorizing their use at that stage as well as their possible use in the future. The Court of Justice, though not excluding that a program with such characteristics may favour "to a certain extent the achievement of economic policy goals", underlines how "such indirect incidences cannot imply that such a program should be equated to an economic policy measure" 61 . Indeed, the definition of such interventions as monetary or economic policy measures depends also on the different kind of the subjects in charge of taking them and on the achievable goals.

${ }^{59}$ See G. Majone, The New European Agencies: Regulation by Information, in "Journal of European Public Policy", 1997, pp. 262-275,

${ }^{60} \mathrm{~B}$. CEURE, The international dimension of the ECB'S asset purchase programme, 11 July 2017, Foreign Exchange Contact Group Meeting, available on the website www.ecb.europa.eu.

${ }^{61}$ See judgement Gauweiler, C-62/14 a/m points 58 and 59. 
On these premises, according to the Court, the fact that a purchase of Government bonds on the secondary markets has been carried out by the ESM and has been qualified as an economic 62 policy measure does not necessarily imply the same evaluation as if it were adopted by the ESCB. The ESCB resorts to such purchase only to the extent necessary to maintain price stability, while the ESM adopts it to preserve stability of the Euro Area.

Therefore, through these remarks, the Court not only endorses and strengthens the approach of the ECB in its release, but also substantially grants it a certain amount of discretionary power in defining the measures provided sufficient proportionality in relation to the assigned goals ${ }^{63}$.

There is also, as a direct consequence, a possible judicial review of what has been communicated and most of all affirmed in the press releases about the adoption of the different measures. As a matter of fact, the only information available about the OMT programme was the press release published on 6 September 2012 after the press conference of the ECB President and a meeting of the Governing Council. It is difficult to refer to the press release as a legally binding act. However, in this context it resulted in impacting on third parts. As for this point Advocate general Cruz Villalón highlighted that "the press conference on 2 August 2012 following the meeting of the Governing Council of the same day and the situation affecting the government bond markets of various Member States at that time all confirm that the ECB's intention in making an announcement about the OMT programme was not just to give an account of internal work on an initiative that was still at the discussion stage but also to produce an effect by making an announcement". So "the OMT programme entailed not the publication of a simple individual act but rather the announcement of a full normative programme, for the future, which included relatively precise conditions and whose purpose was regulatory" 64 .

62 See Pringle, cited above in note 45, point 60.

${ }^{63}$ The Court established that a violation of proportionality only exists if the act is evidently inappropriate in relation to the objectives pursued. See the judgements of 12 December 2006, Case C-380/03, Germany v. Parliament and Council, ECLI:EU:C:2006:722 and of 8 July 2010, Case C-343/09, Afton Chemical Ltd. v. Sec'y of State for Transp. , ECLI:EU:C:2010:419.

${ }^{64}$ Opinion cited above in note 44 , p. 84-85. 
Riassunto - Il lavoro ripercorre ed analizza il ruolo della Banca Centrale Europea e gli interventi adottati durante la crisi finanziaria soffermandosi sul contenuto, la fisionomia ed in modo specifico sulle modalità di comunicazione delle diverse misure adottate. Come risulta dall'analisi, la BCE ha fatto ricorso a misure di politiche monetaria non convenzionali per l'efficacia delle quali gli aspetti comunicativi sono risultati molto importanti. In questo senso le politiche di comunicazione relative alle misure non convenzionali adottate risultano interessanti ed attuali da esaminare perché mostrano come esse siano diventate non solo una modalità di incremento di trasparenza ma un supporto fondamentale per l'efficacia della politica monetaria. 